\title{
How to improve ship crew's work effectiveness through the leadership style, work life balance and employee engagement in Indonesia national shipping
}

\author{
Prasadja Ricardianto $^{a^{*}}$, Ridho Bramulya Ikhsan ${ }^{\mathrm{b}}$, Rini Setiawati $^{\mathrm{a}}$ and Rudy Max Damara Gugat ${ }^{\mathrm{a}}$
}

${ }^{a}$ Trisakti Institute of Transportation and Logistics, Indonesia

${ }^{b}$ Business Management, Binus Online Learning, Bina Nusantara University, Indonesia

\section{H R O N I C L E}

\begin{tabular}{l} 
Article history: \\
Received: July 92019 \\
Received in revised format: July \\
192019 \\
Accepted: August 21,2019 \\
Available online: \\
August 21,2019 \\
\hline Keywords: \\
Employee engagement \\
Leadership style \\
Ship officer \\
Ship crew \\
Work effectiveness \\
Work life balance
\end{tabular}

\section{A B S T R A C T}

The aim of this research is to analyze leadership style, work-life balance, and employee engagement on the ship crew's work effectiveness of 290 ship crews. The study is performed using a sample technique through Proportionate Stratified Random Sampling taken from the population of 1050 ship crew of passengers of vessel at Port of Tanjung Priok, Jakarta, Indonesia. The study uses quantitative approach with Structural Equation Modeling, with the help of the Lisrel program. The result of this study shows that leadership style, work-life balance and employee engagement directly and positively influence the work effectiveness. The benefit for Indonesia National Shipping is that through the improvement of leadership style of the officers, work-life balance, and employee engagement, the Indonesia National Shipping may improve the work effectiveness of every ship crew. The findings provide a model for employee engagement and work effectiveness of national shipping ship crew. The output of this study states that every change in the quality of ship officer's leadership style, quality of work-life balance and employee engagement directly and positively influenced the ship crew's work effectiveness of Indonesia National Shipping.

\section{Introduction}

The object of this study is based on the seven passenger vessels berthing at the Port of Tanjung Priok which are motor vessels with capacity of 2,000 passengers (type 2000), namely Umsini (the vessel which has been operating longest since 1985), Ciremai, Dobonsolo, Kelud, Dorolonda, Nggapulu, and the newest vessel named Gunung Dempo. The study uses the data of passenger vessels which operate more at the Port of Tanjung Priok, considering: 1) customer satisfaction based on annual survey at the Port of Tanjung Priok, 2) the best result of ship's crew training for services with hospitality and service excellence achieved by Kelud, 3) the number of competence certificates owned by ship's crew, and 4) new ship's crew performance in the level of non-commisssioned officer and buck private from the income point of view related to the number of passengers carried by those seven motor vessels. The problem in this study and the previous studies is that the increase of work effectiveness has been influenced by some supporting variables such as compensation, work-life balance, and employee engagement. Some other independent variables which also have relationship with work effectiveness are: employee training, Occupational Safety and Health (OSH), work discipline, working motivation of ship's crew, and ship's service quality. Employee training plays an important role for the improvement of employee's work effectiveness. The training can encourage employees to be more active to work so that they are chosen to attend various training programs held by the company. In the implementation of OSH program, ship's crew will feel safe, get protection and safety assurance, so it will make cost and time efficiencies as well as improve work effectiveness. Work discipline is very necessary because it is one of the elements of employee compliance with all the company's regulations. To have disciplined employees will give significant impacts on the company. The employees motivated in doing their job, develop their skills, and those who receive feedback concerning their

\footnotetext{
* Corresponding author
}

E-mail address: ricardianto@gmail.com (P. Ricardianto) 
previous performance will improve their future ability. On-board safety training is much needed since it positively affects the ship's crew operational performance to improve the work effectiveness (Lasse \& Fatimah, 2016; Pangihutan et al., 2016). Training is a way to have workforce which match the company's need and want, for both new and old ship's crew. The main problems of ship's crew work effectiveness of the passenger vessels berthing at the Port of Tanjung Priok, are found in the level of buck private such as machine installer, oiler, motorman, laundryman and blacksmith. The main question is whether the expected results have been achieved. Poor discipline of those working as steward, ordinary seaman, especially when performing checking; for example, inaccurate ship's lifeboat examination will influence the on-board safety. Shipping company, according to Nurhasanah et al. (2015), should have facilities and equipment to comply with ISM (International Safety Management) Code. Such main factors as safety and accident avoidance in the vessel in addition to the ship construction itself, as well as periodical ship maintenance, must be performed in accordance with the system and procedures and follow the prevailing regulation. The other factor is human resosurces or the ship's crew istself. The other researchers, Berg et al. (2013), study the factors influencing safety from the perspective of ship's crew. Fatigue experienced by the ship's crew due to tight schedule, the possibility of no ship (to work on), bad management, unequal or low salary, equipment with old technology, company's safety culture and recruitment policy are the factors influencing safety.

Safety action in shipping is found to be very effective. Ship's crew are aware of the effectiness of safety when they are working on-board so that they will be accustomed with the standard operation (Wiweko, Thamrin, \& Edi, 2015). In the next research, Nguyen, et al. (2014) reveal the low quality of graduates and skilled seafarers as well as the lack of competent ground executives. In terms of retention, poor working and life condition on board is the main factor that should be paid attention in order to increase the retention of seafarers. This study recommends an effective human resource strategy for shipping companies, so that they can increase their recruitment and lower their retention. Studying sea transportation mode, the main urgent problem is the work effectiveness of ship's crew, especially at the level of non-commissioned officer and buck private, but the buck private level has more problems. Poor discipline, especially in the punctuality of working time, delay of starting time to work, have made the work performed hastily, lowering the work quality, and finally lowering the work effectiveness. The practical benefits of this research are used for the policy makers in the field of sea transportation, especially in the field of transportation at the Ministry of Transportation. The objective of the study and implementation activities in the field of transportation is to provide some insights and consideration for the Government in the framework of policy making and follow-up actions regarding the development plan of the general human resources division at shipping company under the Directorate General of Sea Transportation.

Work effectiveness has four short term criteria; namely quality, productivity, efficiency and satisfaction. Work effectiveness also has five dimensions; namely quantity, quality, reliability, presence, and ability to collaborate (Mathis \& Jackson, 2008:378). The six classifications are deadline fulfillment, work accuracy, degree of complaint received from customers, superordinates, and other departments, loyalty or compliance with quality standard and obedience to the approved budget, and productivity (Mullins, 2010:260). Management makes the right decision to achieve the objectives demanded in an effective way in relation to the lack of sources and variations of limitations and it is a major force to increase the effectiveness of an organization (Tohidi \& Jabbari, 2012). In a study of ship crew previously investigated, human capital in turn, enables companies to improve organizational effectiveness on a short-term basis, and will ultimately build long-term competitive advantage (Sikora, et al., 2016). Quality of service has been conducted research on permanent employees and marine employees of a shipping company (Kadarisman et al., 2016). The increasing the wrong and other deviant behaviors in the workplace has disastrous effects for organizations, such as lowered effectiveness, escalated costs and the organization's declining reputation (Engelbrecht et al., 2017). Another results obtained indicate that if employees are positively motivated, it improves both their effectiveness and efficiency drastically for achieving organizational goals (Nabi et al., 2017). Based on the above theories and researches, from those experts, it can be conceptualized in a concrete way that work effectiveness is the effective performance of an employee based on quality, work quantity, punctuality, satisfaction, and work accuracy taken advantage to achieve the real obectives.

Initially, the concept of leadership style is developed by Bass (1997) and Bass and Riggio (2006), into four dimensions; namely idealized influence, inspirational motivation, intellectual stimulation, and individual consideration. Choo (2007) stated that a key finding of the leadership survey demonstrated that there were perceived substantial gaps in leadership skills such as motivating and inspiring, giving recognition for achievement, and providing feedback. Three groups of leadership style from staff up to managerial level and focus on the strength include autocratic, democratic and laizes-faire. In addition, leadership style is the most prevalent factor that influences employees' attitudes and behaviors including organizational commitment (Clark et al., 2009). Bosiok indicated a significant correlation between the latent dimensions of the creativity construct and those of autocratic, democratic and liberal leadership styles (Sad \& Bosiok, 2013). There are many leadership styles and none is better than the other in any circumstances (Mullins, 2010:282; Robbins \& Coulter, 2013:130). For higher or lower level, a leader may be autocratic or democratic, controller or enabler, job oriented or focus on people (Kotler \& Armstrong, 2014:644). There are leaders who act dictatorship in making decisions and compromise in disputes with employees. The results of the study also argue that leaders have different behaviors and can provide the desired answers (Guluta \& Rusu, 2016). Based on these theories, it can be conceptualized in a concrete way that a better leadership style is autocratic or democratic, ideal influence, intellectual stimulation, and individual consideration. 
There are some work life balance, for the achievement of employees on a balanced satisfaction between work and non-work activities and wider care tasks, as well as other activities and interests (Armstrong \& Taylor, 2014:446-450). There is a need for ability of individuals to devote appropriate amounts of time and energy, both to their work and to life outside their work (Ryan \& Peters, 2015:11). Work-life balance based on the theoretically is the perception of an individual that job and nonjob activities are compatible and they encourage self-development in accordance with his or her current life priorities (Kalliath \& Brough, 2008). Five classifications of work-life balance are: 1) Balance or time management; 2) Having social life out of job; 3) Balance work and personal life; 4) Work-family balance (can meet and be responsible for the family while performing the responsibility in the company); and 5) I am able to stay involved in non-work interests and activities (still having time for hobbies) (Parkes \& Langford, 2008). Furthermore, work-life balance is negatively associated with work demands, intentions to move away and psychological strain, and is positively associated with family and job satisfaction (Timms et al., 2015). The perceived balance between work and rest and the work-life balance have always been a major concern interested in the quality of life and workers and the issue of a wider quality of life (Guest, 2003). Based on these theories and some references from those experts, it can be conceptualized that work-life balance is the ability of employees to be engaged in the balance of work and life with some dimensions; namely 1) time balance, 2) involvement balance, 3) satisfaction balance, 4) work safety balance and 5) the balance between work and family. Employee engagement, developed through general behaviour in the threedimension aspect includes stay and strive. Kenexa offers an engagement index called Kenexa Index from the employee engagement in four dimensions; pride, satisfaction, advocacy, and retention (Tobing, 2016; Wellins \& Bernthal, 2005; Hewitt Associates LLC, 2013). According to Fairlie (2011), the value of meaningful work in Human Resource Development practices involves in employee engagement. Implications for human resource development research and practice are highlighted as possible strategic leverage points for creating conditions that facilitate the development of employee engagement as means for improving organizational performance (Shuck, Reio Jr, \& Rocco, 2011). Engagement is frequently shown when an individual shows the behaviour related to talking positively about the organization (say), having a wish to be a part of the organization (stay), and willingness to make extra efforts that contribute to the organization's success (strive) (Hewitt, 2012).

Engagement, satisfaction, and enthusiasm of an individual to work are three dimensions of Engagement (Kreitner \& Kinicki, 2011:170). Hewitt Associates (2013) developed an employee engagement model through general behaviour in three dimensional aspects, namely Say, Stay and Strive. Engaged workers willingly devote their best efforts to their work in terms of their energy (vigor), sustained attention (absorption) and their sense of purpose (dedication), thereby contributing to the optimal functioning and performance of organizations (Timms et al., 2015). Another analyses, provided support for full mediation whereby there is an indirect (via work engagement) and support for the mediating effects of the three dimensions of work engagement, vigor, dedication, and absorption, in this relationship (Karanika-Murray et al., 2015). Another study, that practically important to human resource management practices in China and theoretically important for the exploration of antecedents of employee engagement was performed by Xie et al. (2016). In Philippines, a study shows that improvements in human resource management practices, particularly in the areas of reward management, yielded positive and significant change in the level of employee engagement. Presbitero (2016) and Anthony-McMann et al. (2017) clarify the highly debated relationship between employee engagement and burnout and challenge of those engagement measures that are conceptually grounded in a burnout-antithesis framework. Implications and avenues for future research were presented by AnthonyMcMann et al. (2017). Employee engagement represents a work-related state of art characterized by feelings of vigor, fulfillment, enthusiasm, absorption and dedication (Eldor \& Vigoda-Gadot, 2017). In Asian countries, the theory and research on employee engagement in the western countries has received less consideration (Gupta, 2017). Engagement based on Knight et al. (2017) is currently a popular topic in many organizations, given its association with employee well-being (Christian et al., 2011, Knight et al., 2017). Based on the above theories and researches, from those experts, it can be concretely conceptualized that employee engagement has sameness in the research dimensions such as vigour, dedication, work consentration (absorption), and loyalty (stay).

\section{Hypothesis}

H1: Leadership Style has influences on Employee Engagement.

$\mathbf{H}_{2}$ : Work Life Balance has influences on Employee Engagement.

$\mathbf{H}_{3}$ : Leadership Style has influences on Work Effectiveness.

H4: Work Life Balance has influences on Work Effectiveness.

Hs: Employee Engagement has influences on Work Effectiveness.

We propose that leadership style, work life balance, and employee engagement are signaling tools that increase work effectiveness of Indonesia shipping crew. Fig. 1 presents the conceptual framework of this research: 


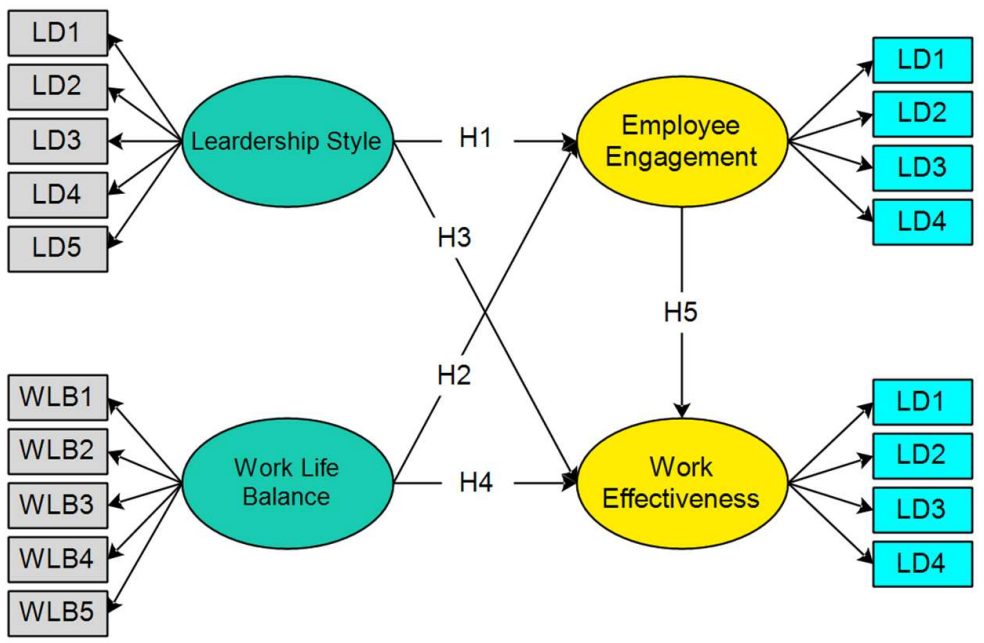

Fig. 1. Conceptual Framework Research Method

\section{Methodology}

There are four latent variables in this research; namely leadership style, work life balance, employee engagement and work effectiveness. Each latent variable is measured by some observable variables/indicators. This research uses quantitative approach with Structural Equation Modeling, aided by Lisrel 8.7.1 program. Hair et al. (2014) explain that the use of SEM enables the simultaneous analysis on a series of relationships and statistically provides efficiency. Structural Equation Modeling is used to test the research hypotheses. The sampling technique is through the clusters of observation unit called Cluster Systematic Sampling. The use of Slovin formula yields a sample of 290 ship's crew out of the 1050 population from seven motor vessels. The result from questionnaire is considered as reliable and valid in the previous trial toward 30 respondents of ship's crew. The results of validity test on the instruments of work effectiveness, leadership style, work-life balance and employee engagement show that most statement items are valid. The results of reliability test on all variables are above 0.9 or having high reliability. The use of Lisrel approach from Structural Equation Modeling (SEM) for quantitative analysis are much made by some previous researchers to test the conceptual framework. The research uses SEM (Eo et al., 2014; Naik \& Bisht, 2014). Some leadership style studies apply SEM (Kim, 2014; Shrestha, 2012). Many other studies examined the effect of work-life balance on employee performance by using SEM models (Tavassoli \& Sune, 2018; Banu, 2016; Haar et al., 2014). Another studies identified the relationship of employee engagement using SEM (Hanaysha, 2016; Anitha, 2014). Some other previous researchers have also noted to use SEM model aided by Lisrel program (Agha et al., 2017; Sadeli, 2015; Rani et al., 2011; Carmeli et al., 2010).

\section{Results and discussion}

\subsection{Confirmatory Factor Analysis of Leadership Style}

Table 1 demonstrates the validity and reliability of leadership style components. Based on the test result of Confirmatory Factor Analysis (CFA) on the construct of leadership style, it is seen that the value of $\lambda$ (loading factor) in every dimension is $>0.5$. It means that all the indicators in the dimension have been valid (first order). Likewise, the value of CR is $\geq 0.70$ and $\mathrm{VE} \geq 0.50$. Thus, it can be concluded that all the indicators used in this study have good validity and reliability values.

Table 1

Validity and Reliability Tests on Leadership Style

\begin{tabular}{cccccccc}
\hline Construct & Dimension & $\boldsymbol{\lambda}$ & $\boldsymbol{\lambda}^{\mathbf{2}}$ & $\mathbf{E}$ & $\mathbf{C R}$ & VE & Interpretation \\
\hline \multirow{2}{*}{ Leadership Style } & LD1 & 0.89 & 0.79 & 0.21 & & & \\
& LD2 & 0.90 & 0.81 & 0.18 & & 0.82 \\
& LD3 & 0.96 & 0.92 & 0.08 & 0.96 & \\
\hline
\end{tabular}

\subsection{Confirmatory Factor Analysis of Work Life Balance}

Table 2 demonstrates the validity and reliability of work-life balance components. Based on the test result of Confirmatory Factor Analysis (CFA) on the construct of work-life balance, it is seen that the value of $\lambda$ (loading factor) in every dimension is $>0.5$. It means that all the indicators in the dimension have been valid (first order). Likewise, the value of CR is $\geq 0.70$ dan VE $\geq 0.50$. Thus, it can be concluded that all the indicators used in this study have good validity and reliability values. 
Table 2

Validity and Reliability Tests on Work-Life Balance

\begin{tabular}{lccccccc}
\hline \multicolumn{1}{c}{ Construct } & Dimension & $\boldsymbol{\lambda}$ & $\boldsymbol{\lambda}^{\mathbf{2}}$ & $\mathbf{e}$ & $\mathbf{C R}$ & VE & Interpretation \\
\hline \multirow{3}{*}{ Work Life } & WLB1 & 0.92 & 0.79 & 0.16 & & \\
Balance & WLB2 & 0.94 & 0.81 & 0.11 & & Valid and Reliable \\
& WLB3 & 0.95 & 0.92 & 0.10 & 0.97 & & \\
& WLB4 & 0.88 & 0.72 & 0.22 & & \\
\hline
\end{tabular}

\subsection{Confirmatory Factor Analysis of Employee Engagement}

Table 3 demonstrates the validity and reliability of employee engagement components. Based on the test result of Confirmatory Factor Analysis (CFA) on the construct of employee engagement, it is seen that the value of $\lambda$ (loading factor) in every dimension is $>0.5$. It means that all the indicators in the dimension have been valid (first order). Likewise, the value of CR is $\geq 0.70$ dan VE $\geq 0.50$. Thus, it can be concluded that all the indicators used in this study have good validity and reliability values.

Table 3

Validity and Reliability Tests on Employee Engagement

\begin{tabular}{lccccccc}
\hline \multicolumn{1}{c}{ Construct } & Dimension & $\boldsymbol{\lambda}$ & $\boldsymbol{\lambda}^{\mathbf{2}}$ & $\mathbf{e}$ & $\mathbf{C R}$ & VE & Interpretation \\
\hline \multirow{3}{*}{$\begin{array}{l}\text { Employee Engage- } \\
\text { ment }\end{array}$} & EE1 & 0.94 & 0.79 & 0.11 & & & Valid and Reliable \\
& EE3 & 0.96 & 0.81 & 0.08 & \multirow{2}{*}{0.98} & 0.91 & \\
\hline
\end{tabular}

\subsection{Confirmatory Factor Analysis of Work Effectiveness}

Table 4 demonstrates the validity and reliability of work effectiveness components.

Table 4

Validity and Reliability Tests on Work Effectiveness

\begin{tabular}{cccccccc}
\hline Construct & Dimension & $\boldsymbol{\lambda}$ & $\boldsymbol{\lambda}^{\mathbf{2}}$ & $\mathbf{e}$ & $\mathbf{C R}$ & VE & Interpretation \\
\hline \multirow{4}{*}{ Work Effectiveness } & WE1 & 0.95 & 0.79 & 0.09 & & & Valid and Reliable \\
& WE2 & 0.95 & 0.81 & 0.09 & \multirow{2}{*}{0.96} & 0.87 & \\
& WE3 & 0.96 & 0.92 & 0.09 & & & \\
\hline
\end{tabular}

Based on the test result of Confirmatory Factor Analysis (CFA) on the construct of work effectiveness, it is seen that the value of $\lambda$ (loading factor) in every dimension is $>0.5$. It means that all the indicators in the dimension have been valid (first order). Likewise, the value of CR is $\geq 0.70$ dan VE $\geq 0.50$. Thus, it can be concluded that all the indicators used in this study have good validity and reliability values.

\subsection{Result of Model Test}

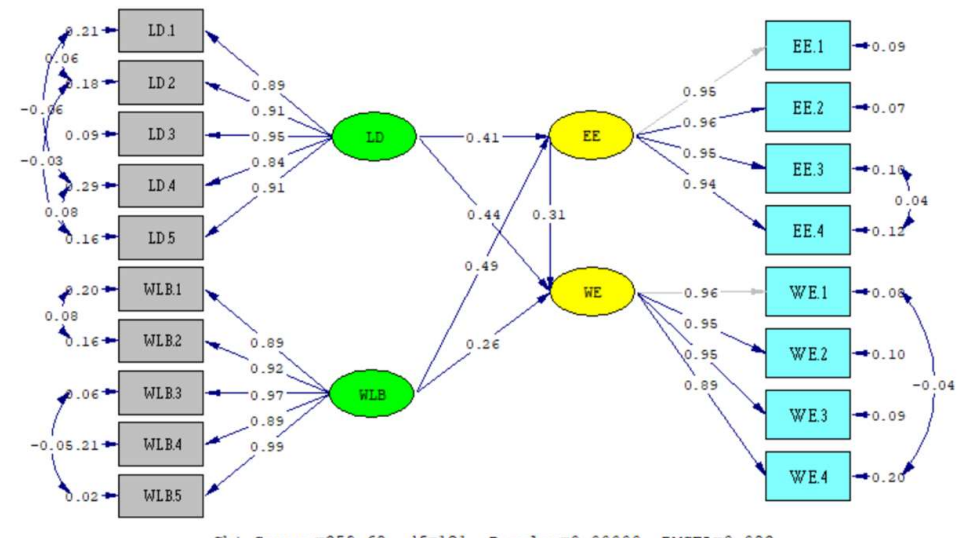

Chi-Square $=359.68, d f=121, \mathrm{P}-\mathrm{value}=0.00000, \mathrm{RMSEA}=0.083$

Fig.2. Research Model 
Goodness of Fit Statistics is an assessment over the whole index value that can become the guidance for assessing whether the designed model can be said as having suitability between the theory-based research model and the empirical research data. SEM does not have a single best statistical test to explain the predictive strength of a model, so it needs some index criteria to assess the model suitability, especially if the the number of samples used is more than 200. All the indices are summarized in one table along with their cuts of value below. Table 5 demonstrates different criteira used for the proposed study.

Table 5

Index of Goodness of Fit Statistics

\begin{tabular}{|c|c|c|c|}
\hline Goodness of Fit Indeks & Cut of Value & Research Result & Remarks \\
\hline \multicolumn{4}{|l|}{ Chi-Square } \\
\hline Chi-Square & Expected $X^{2}<X^{2}$ table & 359.68 & Not good \\
\hline Sig. Probability & $\mathrm{P}>0.05$ & 0.00 & Not good \\
\hline \multicolumn{4}{|l|}{ Absolute Fit Measures } \\
\hline GFI & $\geq 0.90$ & 0.88 & Marginal \\
\hline RMSEA & $\leq 0.08$ & 0.08 & Good \\
\hline Normed Chi-Square & $<2$ or $<5$ & 4.47 & Good \\
\hline \multicolumn{4}{|l|}{ Incremental Fit Indices } \\
\hline NFI & 0.90 & 0.98 & Good \\
\hline NNFI & 0.90 & 0.99 & Good \\
\hline CFI & 0.90 & 0.99 & Good \\
\hline RFI & 0.90 & 0.98 & Good \\
\hline \multicolumn{4}{|l|}{ Parsimony Fit Indices } \\
\hline AGFI & $0-1$ & 0.83 & Marginal \\
\hline PNFI & $0-1$ & 0.78 & Marginal \\
\hline
\end{tabular}

Based on the calculation of the model suitability with some index criteria, eleven criteria are measured and there are two indices which do not fulfill the requirements for model suitability, namely Chi-Square $\left(X^{2}\right)$ and Sig. Probability; whereas the other nine indices are included in the creteria as "good". The expected value of Chi-Square for the model's suitability is less than the value in Chi-Square table and the expected value of Sig. Probability is more than 0.05. Hair et al. (2014) explains that Chi-Square is very sensitive with the use of a big sample. If the number of big research samples is more than 200, then Chi-Square $\left(X^{2}\right)$ must be accompanied by other testing tools. The samples of this study are 290 ship's crew, so the inadequate values of Chi-Square $\left(X^{2}\right)$ and Sig. Probability still can be considered as valid because the other nine index criteria which are tested have fulfilled the requirements for model suitability.

\subsection{Hypothetical Test}

The following is the results of hypothetical test.

Table 6

The Influence of Leadership Style and Work Life Balance on Employee Engagement

\begin{tabular}{|c|c|c|c|}
\hline Path & Coefficient & T-Value & Results \\
\hline Leardership Style $\rightarrow$ Employee Engagement & 0.41 & 7.65 & Influential \\
\hline Work Life Balance $\rightarrow$ Employee Engagement & 0.49 & 8.90 & Influential \\
\hline \multicolumn{4}{|c|}{$\begin{array}{c}\text { Structural Equation } \\
\mathrm{EE}=0.41 \mathrm{LD}+0.49 \mathrm{WLB}+\varepsilon\end{array}$} \\
\hline
\end{tabular}

From Table 6 it is seen that leadership style and work-life balance have influences on employee engagement, thus hypothesis 1 and hypothesis 2 are accepted.

\subsubsection{The influence of leadership style on employee engagement}

The results of the previous relevant research states that leadership style has a direct positive influence on employee engagement. Theoretical study states that leadership style supports employee engagement. Theoretical study by Armstrong (2009) states that leadership style supports engagement. In the previous relevant researches, Leadership style gives a direct positive influences on employee engagement (Wefald et al., 2011; Wefald et al., 2011; Nelson \& Shraim, 2014; Tabak \& Hendy, 2016; Lee et al., 2018). Research gives understanding of some perspectives on leadership style and discusses which leadership factors may be the most effective to ascertain that the employees are still engaged and productive. A conceptual model is needed for further research on the relationship between leadership style and work engagement (Blomme et al., 2015). Appropriate leadership styles and Human Resource practices that encourage engagement need to be nurtured in the organization to drive performance (Popli \& Rizvi, 2016). Leadership styles are positively and significantly related to employee engagement but still democratic leadership styles show stronger relationships with employee engagement (Yao, et al., 2017). The relationship between work engagement and work performance, is specially paid attention because it is focused on performance improvement (Kim et al., 2012). Thus, the result of this research is in accordance with the theoretical study and the results of previous relevant researches. It means leadership style give a direct positive influence on employee engagement. 


\subsubsection{The influence of work-life balance on employee engagement}

Theoretical study states that work-life balance supports employee engagement. Previous research by Parkes and Langford, (2008) stated that work-life balance is necessary for employee engagement and retention in the other organizational climate dimensions. Employee engagement is increasingly seen as a "win-win" strategy for companies, employees and their communities. In addition, work life balance is increasingly important for engagement and influence retention (Susi \& Jawaharrani, 2011). Another research stated that an organization that promotes work-life balance policies and practices will win the benefits of enlarged employee engagement and also positive outcomes depending on a workplace culture that supports the use of work-life initiatives (Namita, 2014). Others provided a framework to develop their engagement strategies while paying attention to the balance of their work life (Mendis \& Weerakkody, 2017). Thus, the result of this research is in accordance with the theoretical study and the previous relevant researches. It means, work-life balance has a direct positive influence on employee engagement.

Table 7

The influence of Leadership Style and Work-Life Balance on Work Effectiveness

\begin{tabular}{|c|c|c|c|}
\hline Path & Coefficient & T-Value & Results \\
\hline Leadership Style $\rightarrow$ Work Effectiveness & 0.44 & 9.43 & Influential \\
\hline Work Life Balance $\rightarrow$ Work Effectiveness & 0.26 & 5.82 & Influential \\
\hline \multicolumn{4}{|c|}{ Structural Equation } \\
\hline
\end{tabular}

From Table 7 it is seen that leadership style and work-life balance have influences on work effectiveness, thus hypothesis 3 and hypothesis 4 are accepted.

\subsubsection{The influence of leadership style on work effectiveness}

The results of previous relevant research state that leadership style has a direct positive influence on work effectiveness. Theoretical study states that leadership style supports work effectiveness. The task is very structured and the leader has a good relationship with the employee (Nanjundeswaraswamy \& Swamy, 2014). Another research states appropriate leadership styles will encourage free flow of information between leaders and employees because this will lead to good organization and employee performance (Advani, 2015). All factors identified according to Anitha, (2014), are predictors of employee engagements, however, variables that have a large impact are the work environment and relationships of the team and coworkers. Employee engagement has a significant impact on employee performance. Organizations must focus on presenting a good environment for employees to work and promote programs that will enhance co-worker relations. In another research by Oktora et al. (2016), partial test shows that leadership style influences (positively and significantly) the performance. This study also reinforces the opinion of Hasibuan et al. (2018) based on the opinion of the Hay Group, Beriapeck and Harter (2014) that; leadership variables can be predicted to directly have an impact on employee work effectiveness. Thus, the result of this research is in accordance with the theoretical study and the results of previous relevant researches.

\subsubsection{The influence of work life balance on work effectiveness}

The results of previous relevant research state that work life balance has a direct positive influence on work effectiveness. Theoretical study states that leadership style supports work effectiveness. The results of the previous relevant research state that work-life balance has a direct positive influence on work effectiveness. The research discussing this influence gives evidence that a better work-life balance leads to improved employee performance and job satisfaction (Mendis \& Weerakkody, 2017). Work-life balance has potentials to implement and monitor the work effectiveness suitable with the program balance in order to improve employee motivation, job satisfaction, productivity, and reduce employee turnover, absenteeism, and increasing talented employee retention (Sheppard, 2016). Thus, the result of this research is in accordance with the theoretical study and the previous relevant researches. It means, work-life balance has a direct positive influence on work effectiveness. Work life balance programs have the potential to significantly increase employee morale, reduce absenteeism, and maintain organizational knowledge, especially during difficult economic times (Lockwood, 2003; Pickering, 2006). In addition, there can be a perception that work-life balance arrangements can be related to an individual's perceived performance and better performance capable of us for taking advantage of work-life balance.

Table 8

The Influence of Employee Engagement on Work Effectiveness

\begin{tabular}{lccc}
\hline \multicolumn{1}{c}{ Path } & Coefficeint & T-Value & Results \\
\hline Employee Engagement $\rightarrow$ Work Effectiveness & 0.31 & 6.45 & Influential \\
\cline { 1 - 2 } & Structural Equation \\
& WE $=0.31 \mathrm{EE}+\varepsilon$ & & \\
\hline
\end{tabular}


From Table 8 it is seen that employee engagement has influences on work effectiveness, thus hypothesis 5 is accepted.

\subsubsection{The influence of employee engagement on work effectiveness}

The results of previous relevant research state that employee engagement has a direct positive influence on work effectiveness. Theoretical study states that employee engagement supports work effectiveness. The results of previous relevant research state that employee engagement has a direct positive influence on work effectiveness. Theoretical study states that employee engagement supports work effectiveness (Robinson et al., 2004). Employee engagement behavior has an impact on the tangible and intangible outcomes. Outcomes were tangibles such as increased performance; while outcomes may take the form of customer loyalty intangibles, intellectual capital, and brand image (Macey et al., 2009). Employee Engagement has influences on Work Effectiveness of ship crew. It is expected that the result of this study will support the theory concerning the variables studied by those experts. Based on Vance, (2006), that failing to address problem performance can erode other employees' engagement and commitment, as their workloads increase and they conclude that the company is willing to tolerate poor performance. Employee's working experiences become the consideration to be engaged in the job which will improve the organizational performance (Carlson et al., 2008). Most research only emphasizes the importance and positive impact of employee engagement on business results, failing to provide a cost-benefit analysis for engagement decisions (Kompaso \& Sridevi, 2010). Engagement strategies deployed by the organization has achieved level of satisfactory (Kaliannan \& Adjovu, 2015). Another researcher, shows that how an organization can increase the level of engagement among employees to improve organizational effectiveness (Hamid, et al., 2018). The direct relationship between leadership style and work engagement is partly mediated by employee perceptions (Ghadi et al., 2013). Thus, the result of this research is in accordance with the theoretical study and the results of previous relevant researches.

\subsubsection{Mediation Effect Test}

This study also performs a mediation effect test since the empirical model that has been formed involves an intervening variable, so it needs to prove whether employee engagement is right to become an intervening variable between leadership style and worklife balance as independent variables and work effectiveness as dependent variable (single mediation). The intervening variable is said to be a perfect mediating variable (perfect mediation) if, after it is added, the influence of exogenous variable on endogenous variable which was initially significant becomes insignificant. Whereas intervening variable is regarded as a partial mediating variable if, after it is added, the influence of exogenous variable on endogenous variable is still significant but the significance decreases and does not go to zero (Preacher \& Hayes, 2004).

Table 10

Single Mediation Test through Employee Engagement

\begin{tabular}{cccccc}
\multicolumn{1}{c}{ Influence } & \multicolumn{2}{c}{ Direct } & \multicolumn{2}{c}{ Indirect } & \multicolumn{2}{c}{ Results } \\
\hline Leardership Style $\rightarrow$ Employee Engagement $\rightarrow$ Work Effectiveness & 0.41 & 7.65 & 0.13 & 5.09 & Partial intervening \\
Work Life Balance $\rightarrow$ Employee Engagement $\rightarrow$ Work Effectiveness & 0.49 & 8.90 & 0.15 & 5.18 & Partial intervening \\
\hline
\end{tabular}

Employee engagement is a partial intervening variable between leadership style and work-life balance and work effectiveness since the direction of direct relationship which is initially significant while after the inclusion of employee engagement its value is still significant but the significance decreases. For example: t-value for the direct influence of leadership style on work effectiveness is 7.65 and after employee engagement is added the t-value decreases to become 5.09 and is still significant because the t-value $>1.96$.

\section{Conclusion and Recommendation}

The integrated conclusion is that work effectiveness in the national shipping companies is directly influenced by the leadership style of ship officer, work life balance, and ship crew engagement. Based on the research findings, the novelty of this research is through the work effectiveness of national shipping companies' ship crew in the dimension of work reliability, through leadership style in the dimension of intellectual stimulation, through work life balance in the dimension of balance between work and family as well as through ship crew's engagement in the dimension of loyalty (stay). Another novelty is that the variable of employee engagement is expected to be able to be used as the element of employee Key Performance Indicator (KPI) especially for national shipping companies' ship crew. Overall, respondents' assessment on the work effectiveness from the average value of its dimensions, the lowest value is on the dimension of punctuality, so it is recommended that ship crew report and analyze discrepancies, accidents and dangerous incidents in a quick, appropriate and accurate way. The proposed study has potential to help national shipping companies such as PT PELNI; PT Pelayaran Bahtera Adhiguna, PT Pelayaran Samudera Djakarta Llyod, Research and Development Institution under the Ministry of Transportation to strengthen the policy on human resources to enhance the work effectiveness of employee, especially ship crew, and it is also recommended to explore it in the further research. This research findings reveal the need of further study using certain methods on the ship officer's 
leadership style in foster a positive work life balance and enhancing engagement as the factor that can improve the work effectiveness of national shipping companies' ship crew.

\section{Acknowledgements}

The Authors would like to thank the editors, the associate editor assigned to this manuscript, Proofreaders and anonymous reviewers for their insightful and helpful comments of this article. The Authors also like to acknowledge and thank the Directorate of Research and Community Service (DRPM), Ministry of Research and Technology and Higher Education Republic Indonesia for their Financial supports. Special thank goes to Ship Officer and crew's ship of Motor Vessel in Port of Tanjung Priok. Thanks also to all respondents who were willing to fill out the questionnaire, Trisakti Institute Transportation and Logistic who have given assignments to Port of Tanjung Priok for their useful insights.

\section{Funding}

This Research Grants Council, University Grants Committee was supported by the Directorate of Research and Community Service (DRPM) Ministry of Research and Technology and Higher Education Republic Indonesia (grant numbers: 025/E3/2017).

\section{References}

Advani, A. (2015). Impact of Transformational and Transactional Leadership Styles on Employees' Performance of Banking Sector in Pakistan. Global Journal of Management and Business Research: Administration and Management, 15(5).

Agha, K., Azmi, F. T., \& Irfan, A. (2017). Work-Life Balance and Job Satisfaction: An Empirical study Focusing on Higher Education Teachers in Oman. International Journal of Social Science and Humanity, 7.(3), 164.

Anitha, J. (2014). Determinants of employee engagement and their impact on employee performance. International Journal of Productivity and Performance Management., 63(3), 308-323.

Anthony-McMann, P. E., Ellinger, A. D., Astakhova, M., \& Halbesleben, J. R. (2017). Exploring Different Operationalizations of Employee Engagement and Their Relationships With Workplace Stress and Burnout. Human Resource Development Quarterly, 28, 163-195.

Armstrong, M. (2009). Amstrong's Handbook of Human Resource Management Practice (11th Eds). London and Philadelphia.: Kogan Page Limited.

Armstrong, M., \& Taylor, S. (2014). Armstrong's Handbook of Human Resource Management Practice. London and Philadelphia: Kogan Page Limited.

Banu, R. A. (2016). A structural equation model: II for work-life balance of IT professionals in Chennai. Serbian Journal of Management, 11(1), 141-148.

Bass, B. M. (1997). Does the transactional-transformational leadership paradigm transcend organisational and international boundaries. American Psychologist, 52(2), 130.

Bass, B. M., \& Riggio, R. E. (2006). Transformasional Leadership (2nd Eds.). London, New Jersey.: Lawrence Erlabaum Associates Publishers.

Berg, N., Storgård, J., \& Lappalainen, J. (2013). The impact of ship crews on maritime safety. Publications from the Centre for Maritime Studies.

Blomme, R. J., Kodden, B., \& Beasley-Suffolk, A. (2015). Leadership theories and the concept of work engagement: Creating a conceptual framework for management implications and research. Journal of Management \& Organization, 21(2), 125144.

Carlson, Witt, Zivnuska, Kacmar, \& Grzywacz. (2008). Supervisor appraisal as the link between family-work balance and contextual performance. Journal of Business and Psychology, 23(1-2), 37-49.

Carmeli, A., Reiter-Palmon, R., \& Ziv, E. (2010). Inclusive leadership and employee involvement in creative tasks in the workplace: The mediating role of psychological safety. Creativity Research Journal, 22(3), 250-260.

Choo, H. G. (2007). Leadership and the workforce in Singapore: evaluations by the Singapore Human Resources Institute. Research and Practice in Human Resource Management, 15(2), 104-114.

Christian, M. S., Garza, A. S., \& Slaughter, J. E. (2011). Work engagement: A quantitative review and test of its relations with task and contextual performance. Personnel Psychology, 64(1), 89-136.

Clark, Hartline, M. D., \& Jones, K. C. (2009). The effects of leadership style on hotel employees' commitment to service quality. Cornell Hospitality Quarterly, 50(2), 209-231.

Eldor, L., \& Vigoda-Gadot, E. (2017). The nature of employee engagement: rethinking the employee-organization relationship. The International Journal of Human Resource Management, 28(3), 526-552.

Engelbrecht, A. S., Wolmarans, J., \& Mahembe, B. (2017). Effect of ethical leadership and climate on effectiveness. SA Journal of Human Resource Management, 15(1), 1-8.

Eo, Y. S., Kim, Y. H., \& Lee, N. Y. (2014). Path analysis of empowerment and work effectiveness among staff nurses. Asian Nursing Research, 8(1), 42-48.

Fairlie, P. (2011). Meaningful work, employee engagement, and other key employee outcomes: Implications for human resource development. Advances in Developing Human Resources, 134, 508-525. 
Ghadi, M. Y., Fernando, M., \& Caputi, P. (2013). Transformational leadership and work engagement: The mediating effect of meaning in work. Leadership \& Organization Development Journal, 34(6), 532-550. https://doi.org/10.1108/LODJ10-2011-0110.

Guest, D. E. (2003). Perspectives on the Study of Work-Life Balance. Social Science Information, 41(2), $261-266$.

Guluta, M. C., \& Rusu, C. (2016). Leadership styles and managerial behavior in Romanian companies. Polish Journal of Management Studies, 13(2), 69-80.

Gupta, M. (2017). Corporate Social Responsibility, Employee-Company Identification, and Organizational Commitment: Mediation by Employee Engagement. Current Psychology, 36(1), 101-109.

Haar, J. M., Russo, M., Suñe, A., \& Ollier-Malaterre, A. (2014). Outcomes of work-life balance on job satisfaction, life satisfaction and mental health: A study across seven cultures. Journal of Vocational Behavior, 85(3), 361-373.

Hair, J. F., Black, W. C., Babin, B. J., \& Anderson, R. E. (2014). Multivariate Data Analysis (7th eds.). Pearson Education Limited.

Hamid, M., Javed, T., Sarfraz, F., \& Iltaf, M. (2018). Impact of Employee Engagement on Organizational Effectiveness. Global Journal of Economics and Business Administration, 3.

Hanaysha, J. (2016). Testing the effects of employee engagement, work environment, and organizational learning on organizational commitment. Procedia-Social and Behavioral Sciences, 229, 289-297.

Hasibuan, P. E., Akbar, M., \& Suyatno, T. (2018). The Effect of Leadership, Employee Engagement, and Self Learning on Effectiveness of Employee's Work. International Journal of Scientfic Research and Management, 6(7), 522-529.

Hewitt, A. (2012). Trends in Global Employee Engagement.

Hewitt Associates LLC. (2013). Employee engagement higher at double digit growth companies.

Kadarisman, M., Sudewo, G. C., \& Pahala, Y. (2016). Pemberdayaan Karyawan Dan Kualitas Pelayanan Pada Perusahaan Pelayaran. Jurnal Manajemen Transportasi \& Logistik, 3(3), 339-348.

Kaliannan, M., \& Adjovu, S. N. (2015). Effective employee engagement and organizational success: a case study. ProcediaSocial and Behavioral Sciences, 172, 161-168.

Kalliath, T., \& Brough, P. (2008). Work life balance: A review of the meaning of the balance construct. Journal of Management \& Organization, 14(3), 323-327.

Karanika-Murray, M., Duncan, N., Pontes, H. M., \& Griffiths, M. D. (2015). Organizational identification, work engagement, and job satisfaction. Journal of Managerial Psychology, 30(8), 1019-1033.

Kim, H. (2014). Work-Life Balance and Employees' Performance: The Mediating Role of Affective Commitment. Global Business and Management Research: An International Journal, 6(1), 38.

Kim, W., Kolb, J. A., \& Kim, T. (2012). The relationship between work engagement and performance: A review of empirical literature and a proposed research agenda. Human Resource Development Review, 12(3), 248-276.

Knight, C., Patterson, M., \& Dawson, J. (2017). Building work engagement: A systematic review and meta-analysis investigating the effectiveness of work engagement interventions. Journal of Organizational Behavior, 38.(6), 792-812.

Kompaso, S. M., \& Sridevi, M. S. (2010). Employee engagement: The key to improving performance. International Journal of Business and Management, 5(12), 89.

Kotler, P., \& Armstrong, M. (2014). Principle Of Marketing (15th eds.). New Jersey: Pearson Prentice Hall.

Kreitner, R., \& Kinicki, A. (2011). Organizational Behavior (9th Eds.). New York: McGraw-Hill Irwin.

Lasse, D., \& Fatimah, F. (2016). Pelatihan Keselamatan bagi Anak Buah Kapal. Jurnal Manajemen Bisnis Transportasi Dan Logistik, 2(2), 257-266.

Lee, M. C. C., Idris, M., \& Tuckey, M. (2018). Supervisory coaching and performance feedback as mediators of the relationships between leadership styles, work engagement, and turnover intention.

Lockwood, N. R. (2003). Work/Life Balance Challenges and Solutions.

Macey, W. H., Schneider, B., Barbera, K. M., \& Young, S. A. (2009). Employee Engagement, tools for analysis, practice and competitive advantage. Chichester, West Sussex, UK: Wiley-Blackwell.

Mathis, R. L., \& Jackson, J. H. (2008). Manajemen Sumber Daya Manusia. Jakarta: Salemba Empat.

Mendis, M. D. V. S., \& Weerakkody, W. A. S. (2017). The impact of work life balance on employee performance with reference to telecommunication industry in Sri Lanka: a mediation model. Kelaniya Journal of Human Resource Management, 12(1).

Mullins, L. J. (2010). Management and Organizational Behavior. Edinburgh Gate Harlow. England: Prentice-Hall.

Nabi, M. N., Syduzzaman, M., \& Munir, M. S. (2017). THE IMPACT OF MOTIVATION ON EMPLOYEE PERFOR MANCES: A CASE STUDY OF KARMASANGSTHAN BANK LIMITED, BANGLADESH. International Journal of Business and Management Review, 5(4), 57-79.

Naik, Y. N., \& Bisht, M. (2014). Structural Equation Model for Effectiveness of Technical Managers in Information Technology Industry. International Journal of Supply Chain Management, 3(3).

Namita. (2014). Work-Life Balance In India - The Key Driver Of Employee Engagement. International Journal of Management and Commerce Innovations., 2(1), 109.

Nanjundeswaraswamy, T. S., \& Swamy, D. R. (2014). Leadership styles. Advances in Management, 7(2), 57.

Nelson, S. A., \& Shraim, O. (2014). Leadership behaviour and employee engagement: a Kuwaiti services company. International Journal of Human Resources Development and Management, 14(1-3), 119-133.

Nguyen, T. T., Ghaderi, H., Caesar, L. D., \& Cahoon, S. (2014). Current challenges in the recruitment and retention of seafarers: an industry perspective from Vietnam. The Asian Journal of Shipping and Logistics, 30(2), $217-242$. 
Nurhasanah, N., Joni, A., \& Shabrina, N. (2015). Persepsi Crew dan Manajemen dalam Penerapan Ism Code Bagi Keselamatan Pelayaran dan Perlindungan Lingkungan Laut. In PROSIDING SEMINAR NASIONAL MULTI DISIPLIN ILMU\&CALL FOR PAPERS UNISBANK (SENDI U).

Oktora, J., Rizan, M., \& Situngkir, S. (2016). Effect Of Transactional And Transformational Leadership Style, Motivation And Competence To Performance Of Employees PT. Sanjayatama Lestari. Jurnal Riset Manajemen Sains Indonesia, 7(2), 279-301.

Pangihutan, A., Thamrin, M., \& Suparman, A. (2016). Services Quality Of Ship Agency Services And Interpersonal Communication In Shipping Companies. Jurnal Manajemen Transportasi \& Logistik, 3(2).

Parkes, L. P., \& Langford, P. H. (2008). Work-life balance or work-life alignment? A test of the importance of work-life balance for employee engagement and intention to stay in organizations. Journal of Management and Organization, 14.

Pickering, D. I. (2006). The relationship between work-life conflict/work-life balance and operational effectiveness in the Canadian Forces (No. DRDC-TR-2006-243).

Popli, S., \& Rizvi, I. A. (2016). Drivers of employee engagement: The role of leadership style. Global Business Review, 17(4), 965-979.

Preacher, K. J., \& Hayes, A. F. (2004). SPSS and SAS procedures for estimating indirect effects in simple mediation models. Behavior Research Methods, Instruments, \& Computers, 36(4), 717-731.

Presbitero, A. (2016). How do changes in human resource management practices influence employee engagement? A longitudinal study in a hotel chain in the Philippines. Journal of Human Resources in Hospitality \& Tourism, 16(1), 5670.

Rani, S., Kamalanabhan, T. J., \& Selvarani, M. (2011). Work/life balance reflections on employee satisfaction. Serbian Journal of Management, Serbian Journal of Management, 6(1), 85-96.

Robbins, S. P., \& Coulter, M. (2013). Management. New Jersey: Pearson Prentice Hall.

Robinson, D., Perryman, S., \& Hayday, S. (2004). The Drivers of Employee Engagement. North, $408,12-15$. https://doi.org/IES Report No. 408.

Ryan, M. K., \& Peters, K. (2015). Leadership and Work-life Balance. London: Leadership Foundation for Higher Education. Retrieved from https://www.lfhe.ac.uk/en/research-resources/publications-hub/HELMs/leadership-and-worklifebalance.cfm.

Sad, N., \& Bosiok, D. (2013). Leadership styles and creativity. Online Journal of Applied Knowledge Management, 1(2), 6477.

Sadeli, J. (2015). The Influence Of Leadership, Talent Management, Organizational Cultureand Organizational Support On Employee Engagement. International Research Journal of Business Studies, 5(3).

Sheppard, G. (2016). Work-life balance programs to improve employee performance. Walden University.

Shrestha, A. K. (2012). Leadership Styles, Subordinates' Satisfaction with the Leader and Perceived Effectiveness. (paper No. $5)$.

Shuck, B., Reio Jr, T. G., \& Rocco, T. S. (2011). Employee engagement: an examination of antecedent and outcome variables. Human Resource Development International, 14(4).

Sikora, D. M., Thompson, K. W., Russell, Z. A., \& Ferris, G. R. (2016). Overqualified human resources to promote organizational effectiveness and competitive advantage. Journal of Organizational Effectiveness: People and Performance, 3(1), 23-42.

Susi, S., \& Jawaharrani, K. (2011). Work-Life Balance: The key driver of employee engag ement. ASIAN JOURNAL OF MANAGEMENT RESEARCH, 2(1), 474-476.

Tabak, F., \& Hendy, N. T. (2016). Trust as a Mediator of the Impact of Organizational Job Embeddedness and Perceived Organizational Support. Organization Management Journal, 13(1), 21-31.

Tavassoli, T., \& Sune, A. (2018). A National study on the antecedents and outcomes of work-life balance in Iran. PEOPLE: International Journal of Social Sciences, 3(3).

Timms, C., Brough, P., O’Driscoll, M., Kalliath, T., Siu, O. L., Sit, C., \& Lo, D. (2015). Positive pathways to engaging workers: work-family enrichment as a predictor of work engagement. Asia Pacific Journal of Human Resources, 53, 490510.

Tobing, D. S. K. (2016). The effect of compensation, career development, work-family support on job satisfaction. Polish Journal of Management Studies, 14(1), 206-213.

Tohidi, H., \& Jabbari, M. M. (2012). Innovation as a success key for organizations. Procedia Technology, 1, $560-564$.

Vance, R. J. (2006). Employee engagement and commitment. SHRM Foundation, 1-53.

Wefald, A. J., Reichard, R. J., \& Serrano, S. A. (2011). Fitting engagement into a nomological network: The relationship of engagement to leadership and personality. Journal of Leadership \& Organizational Studies, 18(4), 522-537.

Wellins, R. S., \& Bernthal, P. (2005). Development Dimensions In Employee Engagement: The Key To Realizing Competitive Advantage.

Wiweko, A., Thamrin, M., \& Edi, D. W. (2015). The Effect of Vessel Seaworthiness and Crew 's Competence on Marine Safety. Jurnal Manajemen Transportasi \& Logistik, 2(3), 287-296.

Xie, T., Shi, Y. N., \& Zhou, J. (2016). The adverse effect of materialism on employee engagement in China. Journal of Chinese Human Resource Management, 7(2), 100-114. https://doi.org/10.1108/JCHRM-07-2016-0013

Yao, L., Kee Shin Woan, F. L., Ahmad, M. H. B., \& Kuantan, G. (2017). The Relationship between Leadership Styles and Employee Engagement: Evidences from Construction Companies in Malaysia. The Social Sciences, 12, 984-988. 
C 2020 by the authors; licensee Growing Science, Canada. This is an open access article distributed under the terms and conditions of the Creative Commons Attribution (CCBY) license (http://creativecommons.org/licenses/by/4.0/). 